Available online at GSC Online Press Directory

GSC Biological and Pharmaceutical Sciences

e-ISSN: 2581-3250, CODEN (USA): GBPSC2

Journal homepage: https://www.gsconlinepress.com/journals/gscbps

(RESEARCH ARTICLE)

\title{
Anti-anaemic effects of Moringa oleifera seeds (Lam) in protein energy
}

\section{malnourished rats}

Jegede E. Raphael *, Francis O. Atanu, Suleiman S. Mohammed and Suleiman I. Abdulrahman

Department of Biochemistry, Kogi State University, Anyigba.

Publication history: Received on 08 October 2020; revised on 17 October 2020; accepted on 22 October 2020

Article DOI: https://doi.org/10.30574/gscbps.2020.13.1.0337

\begin{abstract}
The effects of defatted Moringa oleifera seed (L) on haemotological indices and body weight was evaluated in rat model of Protein Energy Malnutrition (PEM). Protein Energy Malnutrition is associated with muscle degeneration and anaemia. Protein Energy Malnutrition (PEM) was induced in fifteen (15) rats by feeding them with low protein diet (3\% fish meal protein) and water for twenty eight days. Five (5) rats served as positive control (Group A) received commercial feed containing 21\% crude protein. The PEM rats were assigned to three groups namely B, C and D. Group $\mathrm{B}$ and $\mathrm{C}$ were fed with recovery diets ad libitum for another twenty eight days. Group B received feed containing $20 \%$ Fishmeal protein and Group C received feed containing 20\% defatted M. oleifera seed. Group D were Protein-energy malnourished rats maintained on protein deficient diet ( $3 \%$ fish meal protein). Protein energy malnourished rats had significantly reduced $(\mathrm{p}<0.05)$ body weight and haematological indices with exception of the Mean Capsular Volume (MCV) and Mean Capsular Haemoglobin $(\mathrm{MCH})$ which significantly $(\mathrm{p}<0.05)$ increased. Phenotypical examination revealed that PEM animals had characteristic typical of catabolic states, which include, retarded growth, loss of hair, scaly tail etc. The recovery diets containing $20 \%$ fishmeal protein or $20 \%$ M. oleifera in place of $3 \%$ fishmeal caused significant $(\mathrm{p}<0.05)$ increase in the Haematological Indices (with exception of MCV and MCH which decreased significantly) and body weight when compared with the malnourished group D. The study support the claims that PEM can cause muscle degeneration and disturbance to haematological parameters. Furthermore, supplementation of diet with M. oleifera seeds ameliorate muscle degeneration and anaemia in PEM rats comparatively similar to $20 \%$ fish meal.
\end{abstract}

Keywords: Malnutrition; Moringa oleifera; Anaemia; Potein-energy; Body weight.

\section{Introduction}

The World Health Organization (WHO) defines Malnutrition as deficiencies, excesses or imbalances in the intake of energy and/or nutrients [1]. This implies that two main kind of malnutrition is possible: overnutrition (which causes obesity) and undernutrition (which causes kwashiorkor). However, in scientific and everyday language, malnutrition is used to refer to deficiency of calories, protein and micronutrients [2].

Protein Calories Malnutrition (PCM) is a syndrome in which anaemia together with multivitamin and mineral deficiency may be present [3]. The lack of iron has been considered as being the main cause of anaemia in malnutrition. Anaemia in experimental malnutrition presents a decrease in iron incorporation and in the number of reticulocytes, and furthermore, an interruption of the maturation process of erythroblasts [3]. Studies demonstrate that in rats, a decrease in erythropoietin occurred due to the reduced ingestion of protein [3]. Protein malnutrition induces structural alterations in lymphoid organs, especially in thymus-dependant areas [4]. Protein deficiency leads to lymphopenia, thymus, spleen and lymph node involution, which is particularly intense in the thymus and spleen [5].

\footnotetext{
${ }^{*}$ Corresponding author: Raphael E. Jegede; Tel: +2348039736256; Email:jegede.er@ksu.edu.ng 
Moringa oleifera Lam (M. Pteriogosperma) belongs to the monogeneric family Moringaceae and it is one of the best known, most widely distributed and naturalized species [6]. It is popularly known as drumstick or horseradish in English and locally known as 'Zogalegandi' in Hausa, 'Eweigbale' in Yoruba and 'Okweoyibo' in Igbo and "Anahuo" in Ebira [7]. It has numerous medicinal uses, which have long been recognized in Ayurvedic and Unani systems of medicines [8]. Many parts of this plant i.e., leaves, immature pods, flowers and fruits are edible and are used as a highly nutritive vegetable in many countries [9].

Several biological properties ascribed to various parts of this plant have been reviewed in the past and these include its use as an antioxidant, anticarcinogenic, antiulcer, antibacterial, and antifungal [10]. Phytochemical analyses have shown that its leaves are particularly rich in potassium, calcium, phosphorous, iron, vitamins A and D, essential amino acids as well as antioxidants such as $\beta$-carotene, vitamin $C$, and flavonoids [11]. Moringa is especially useful for low amount of calcium in the blood serum and it can deliver to the body the calcium needed in a safe way. By providing abundant Calcium, Moringa oleifera helps prevent Anemia [7].

Studies on proximate and phytonutrient analysis of the leaf also showed that it has high percentage of carbohydrate and protein which compared favourably with other high protein/ carbohydrates plant sources [12]. It is therefore a potential leaf source of food that is suitable for fortification of foods and their use as nutritional supplements is highly promising [12]. Moreover, its fruit pod and leaves have been used to combat malnutrition, especially among infants and nursing mothers for enhancing milk production [13]. This research was designed to study the effects of defatted Moringa oleifera seed extract on full blood count in the serum of rats maintained on protein deficient diet ( $3 \%$ protein) for muscle degeneration as a model and comparing its effect with a standard protein source that is fish meal.

\section{Material and methods}

\subsection{Chemicals and Reagents}

All reagents used are of analytical grade and were procured from $\mathrm{BDH}, \mathrm{UK}$.

\subsection{Plant Materials and Authentication}

Moringa oleifera seeds were obtained from the premises of Faculty of Agriculture, Kogi State University Anyigba, Nigeria. They were authenticated at the Botany Department of the University.

\subsection{Experimental Animals}

Albino rats used were obtained from the small Animal Holding Unit of the Department of Biochemistry, Kogi State University, Anyigba, Nigeria. Twenty (20) albino rats of weanling ages (average weight of $57 \pm 1.73 \mathrm{~g}$ ) were used for the experiment. The environment was kept cleaned and disinfected. The animals were kept apart in metabolic cage for 1 week to acclimatize to their environment. The animals were fed on normal rat feed and water. At the start of the experiments, the weight of the rats was determined using a standard weighing scale for rats.

\subsection{Induction of Protein Energy Malnutrition and Animal Grouping}

Twenty (20) weanling female albino rats were used for the study. Protein Energy Malnutrition (PEM) was induced in fifteen (15) rats by feeding them with low protein diet for 28days according to the method of Jegede et al., 2018 [7]. The composition of the diet is as shown in Table 1 . These PEM rats were then divided into three groups B, C and D, each of five rats. Group B and C were fed with recovery diets and water ad libitum for another twenty eight days. Group B received feed supplemented with 20\% Protein Fishmeal and Group C received feed supplemented with 20\% M. oleifera seed. Group D received PEM feed containing 3\% fish meal protein. Positive control (Group A) received commercial feed obtained from Vital Feeds Ltd. 
Table 1 Composition of Protein Energy Malnutrition diet.

\begin{tabular}{|l|c|}
\hline \multicolumn{1}{|c|}{ Component } & \% composition (w/w) \\
\hline Grounded fish /Moringa oleifera & 4 \\
\hline Pulverized maize husk & 53 \\
\hline Composite VITAFLASH AMINO WSP & 3 \\
\hline Palm kernel oil & 5 \\
\hline Sucrose & 35 \\
\hline
\end{tabular}

VITAFLASH AMINO WSP (vitamin-Amino Acids):vitamin A 10,000,000 IU; vitamin D3 2,000,000 IU; vitamin E 15,000 mg; vitamin K3 2,500mg; vitamin B1 1,000mg; vitamin B2 2,000mg; vitamin B6 2,000mg; vitamin B12 10,000mg; folic acid 300mg; Ca-d-pantothenate 7,500mg; nicotine acid 20,000mg; choline chloride 15,000mg; vitamin C 40,000mg;DL-Methionine 50,000mg; L-Lysine 50,000mg; amino acids 52,000mg (cysteine,tryptophan,arginine,threonine,isoleucine,leucine,valine,histidine,phenylanine,tyrosine and glycine).

\subsection{Preparation of Moringa oleifera Seed}

Moringa oleifera seeds were oven dried at $60 \mathrm{oC}$ and pulverized. Lipids were extracted from the pulverized seed of Moringa oleifera using n-hexane via the batch solvent method.

Briefly, a known weight of the pulverized Moringa oleifera seeds was weighed into a dry conical flask, n-hexane was added and the flask shaken vigorously. The sample was then allowed to stand for 24 hours. The supernatant comprising of the organic solvent and the aqueous phase were then decanted.

This procedure was repeated twice to improve the efficiency of the extraction process. The defatted seed (residue) was then spread on foil and airา-dried at room temperature.

\subsection{Formulation of Experimental Diet}

The composition of the experimental Isocaloric Protein Diet according to Jegede et al., (2018) [7] is presented in Table 1 and 2. Each component of the experimental feed was weighed, thoroughly mixed and addition of sufficient distilled water to form pellet.

Table 2 Composition of Recovery Diet.

\begin{tabular}{|l|c|}
\hline \multicolumn{1}{|c|}{ Component } & \% composition (w/w) \\
\hline Grounded fish /Moringa oleifera & 10 \\
\hline Pulverized maize husk & 47 \\
\hline Composite VITAFLASH AMINO WSP & 3 \\
\hline Palm kernel oil & 5 \\
\hline Sucrose & 35 \\
\hline
\end{tabular}

VITAFLASH AMINO WSP (vitamin-Amino Acids):vitamin A 10,000,000 IU; vitamin D3 2,000,000 IU; vitamin E 15,000 mg; vitamin K3 2,500mg; vitamin B1 1,000mg; vitamin B2 2,000mg; vitamin B6 2,000mg; vitamin B12 10,000mg; folic acid 300mg; Ca-d-pantothenate 7,500mg; nicotine acid 20,000mg; choline chloride 15,000mg; vitamin C 40,000mg;DL-Methionine 50,000mg; L-Lysine 50,000mg; amino acids 52,000mg (cysteine,tryptophan,arginine,threonine,isoleucine,leucine,valine,histidine,phenylanine,tyrosine and glycine).

\subsection{Animal sacrifice}

On the 28th day post treatment, animals were sacrificed by cervical dislocation. Blood was collected by cardiac puncture.

\subsection{Haematological Analysis}

The haematological parameters analyzed include, red blood cell count, white blood cell count, blood haemoglobin, full blood count. These were analyzed using automated haematological analyzer (Haematocrit).

\subsection{Statistical Analysis}

All data are expressed as the mean of five replicates \pm standard error of mean (SEM). Statistical evaluation of data was performed by SPSS version 20. Using one way analysis of variance (ANOVA), followed by Duncan's posthoc test for multiple comparisons. Values were considered statistically significant at $\mathrm{p}<0.05$ (confidence level $=95 \%)$. 


\section{Results}

\subsection{Morphological Appearance}

The characteristics appearance of the protein energy malnourished rats [Rats fed with Isocaloric Protein diet (3\% Protein)] in the first 4 weeks includes development of round face, loss of appetite, characteristic loss of fur (severe in the 4th week), on-set of muscle wasting (atrophy), scaly tail (more prominent during the 4th week), presence of sores on the tails, severe fur loss in the 4th week, stunted growth with no significant gain in weight, sparse fur on skin, reduced growth rate at the end of 4 th week and muscle atrophy still persisted. These morphological features of the protein energy malnourished rats treated with $20 \%$ fish meal based diet did not improve. However, the group treated with $20 \%$ M. oleifera showed recovery of hair growth, disappearance of sores on the tail and weight gain.

\subsection{Body Weight}

Table 3 shows the effect of the formulated diet on body weight of the rats. The study showed that there was significant decrease $(\mathrm{P}<0.05)$ in body weight in PEM group (group D) compared with positive control (group A). During the recovery period, the group that was fed with $20 \%$ defatted $M$. oleifera seed diet showed little body weight increase (though not significant); $>0.05$ but $20 \%$ fishmeal based diet fed group showed decrease body weight as compared to PEM group.

Table 3 Effect of recovery diet on body weight of Protein Energy Malnourished (PEM) rats as compare with Positive Control group.

\begin{tabular}{|l|l|l|l|l|}
\hline \multicolumn{5}{|c|}{ Body weight } \\
\hline Week & $\begin{array}{c}\text { Positive Control } \\
\text { Group A }\end{array}$ & $\begin{array}{c}\text { PEM+ 20\% fishmeal } \\
\text { Group B }\end{array}$ & $\begin{array}{c}\text { PEM + 20\% Moringa } \\
\text { Group C }\end{array}$ & $\begin{array}{c}\text { PEM control } \\
\text { Group D }\end{array}$ \\
\hline Initial & $57.00 \pm 1.730^{\mathrm{a}}$ & $52.00 \pm 1.789^{\mathrm{a}}$ & $58.33 \pm 1.229^{\mathrm{a}}$ & $53.893 \pm 1.501^{\mathrm{a}}$ \\
\hline Week 1 & $71.00 \pm 2.733^{\mathrm{b}}$ & $54.33 \pm 4.112^{\mathrm{a}}$ & $51.50 \pm 2.363^{\mathrm{a}}$ & $59.542 \pm 1.651^{\mathrm{a}}$ \\
\hline Week 2 & $92.00 \pm 2.477^{\mathrm{b}}$ & $48.67 \pm 2.076^{\mathrm{a}}$ & $57.17 \pm 2.651^{\mathrm{a}}$ & $60.458 \pm 2.10^{\mathrm{a}}$ \\
\hline Week 3 & $100.5 \pm 2.363^{\mathrm{b}}$ & $50.83 \pm 3.754^{\mathrm{a}}$ & $53.50 \pm 2.110^{\mathrm{a}}$ & $56.083 \pm 1.551^{\mathrm{a}}$ \\
\hline Week 4 & $108.17 \pm 2.372^{\mathrm{b}}$ & $51.17 \pm 3.928^{\mathrm{a}}$ & $53.50 \pm 3.019^{\mathrm{a}}$ & $49.458 \pm 1.593^{\mathrm{a}}$ \\
\hline
\end{tabular}

Values are expressed as means of five (5) replicates \pm SEM (Standard Error of Mean) values with different superscripts across the column are statistically different $(\mathrm{p}<0.05)$.

\subsection{Haematological Profile}

The result of the haematological profile of rats is presented in Tables 4. All the haematological parameters assessed decreased significantly in PEM rats except MCH and MCV which increased. However same indices increased significantly $(\mathrm{p}<0.05)$ after treatment except MCH and MCV which decreased as compared to the control. These differences were only significant in $\mathrm{MCH}, \mathrm{MCV}, \mathrm{PCV}, \mathrm{RBC}(\mathrm{p}<0.05)$.

Table 4 Haemotological Indices of the PEM rats and after Treatment

\begin{tabular}{|c|c|c|c|c|c|c|c|}
\hline & \multicolumn{7}{|c|}{ Haematological indices } \\
\hline Group & HCT (\%) & $\mathrm{HGB}(\mathrm{g} / \mathrm{dl})$ & $\mathrm{MCH}(\mathrm{pg})$ & $\operatorname{MCV}(\mathrm{fl})$ & $\operatorname{PLT}\left(10^{4} \mu \mathrm{l}\right)$ & $\mathrm{RBC}\left(10^{5} / \mu \mathrm{l}\right)$ & $\begin{array}{l}\text { WBC } \\
\left(10^{2} / \mu \mathrm{l}\right)\end{array}$ \\
\hline $\mathrm{PC}$ & $47.37 \pm 4.28^{a}$ & $14.28 \pm 1.00^{\mathrm{a}}$ & $17.73 \pm 0.28^{a}$ & $58.53 \pm 0.89^{a}$ & $87.98 \pm 7.62^{a}$ & $80.80 \pm 13.28^{a}$ & $98.25 \pm 9.11^{\mathrm{a}}$ \\
\hline MO & $49.20 \pm 3.61^{\mathrm{a}}$ & $14.95 \pm 1.00^{\mathrm{a}}$ & $16.83 \pm 0.23^{\mathrm{a}}$ & $55.50 \pm 0.37 \mathrm{a}$ & $56.30 \pm 10.88^{\mathrm{b}}$ & $89.13 \pm 13.52^{\mathrm{a}}$ & $83.50 \pm 7.29$ a \\
\hline FM & $47.35 \pm 2.00^{\mathrm{a}}$ & $13.68 \pm 0.61^{\mathrm{a}}$ & $16.30 \pm 0.74^{\mathrm{a}}$ & $57.82 \pm 0.99^{a}$ & $52.35 \pm 2.56^{b}$ & $84.18 \pm 7.12^{\mathrm{a}}$ & $67.50 \pm 7.76^{\mathrm{a}}$ \\
\hline PEM & $40.48 \pm 0.85$ & $13.25 \pm 0.32^{\mathrm{a}}$ & $25.12 \pm 0.82^{b}$ & $76.65 \pm 2.05^{b}$ & $17.58 \pm 1.18^{c}$ & $43.78 \pm 4.24 \mathrm{~b}$ & $63.75 \pm 10.36^{\mathrm{a}}$ \\
\hline
\end{tabular}

Values are expressed as means of five (5) replicates \pm SEM (Standard Error of Mean) values with different superscripts across the column are statistically different $(\mathrm{p}<0.05) . \mathrm{RBC}=$ Red blood cells, $\mathrm{WBC}=$ White blood cells, $\mathrm{HGB}=$ haemoglobin, $\mathrm{PVC}=\mathrm{Pack}$ cell volume, $\mathrm{MCH}=\mathrm{Mean}$ corpuscular Haemogobin, MCV = M Mean Corpuscular Volume, HCT = Haematocrit, PLT = platelet; Group PC= control animals, Group PEM= malnourished with low protein based diet, Group MO= PEM treated with 20\% M. oleifera, based diet Group FM = PEM treated with $20 \%$ Fish meal based diet. 


\section{Discussion}

Malnutrition (PEM) is associated with morphological changes which includes; oedema, diarrhoea, weight loss, alopecia, retinopathy and vulnerability to opportunistic infections and reduction in total protein [14]. This aligns with the result obtained from this research. However, changes in morphology resulting from malnutrition are often reversed by improved nutrition. The result of this study revealed that the adverse morphological changes observed in the test animals were improved with the administration of the improved diets though with different capacity.

The significant reduction in body weight when PEM group was compared with positive control may be due low protein intake. In Protein insufficient intake, the endogenous amino acids generated mainly from skeletal muscle proteolysis become the source of amino acids for protein synthesis and the obligatory nitrogen losses [6]. These results are in alignment with other studies showing that protein malnutrition reduces body mass in animal subjects [15] [16].

The significant decrease $(\mathrm{p}<0.05)$ observed in the hematological indices when protein energy malnourished (PEM) control group was compared with positive control group, may be due to the low iron; the mineral that helps produce red blood cell, inhibition of haemopoesis, one of the common complications of protein-energy malnutrition is anaemia [17]. Animals fed on protein calorie malnourished diets had been reported to have significant reduction in haemoglobin concentrations [18]. It has also been well documented that kwashiorkor and marasmus (protein energy malnutrition) patients had low levels of haematological indices [19]. Similarly, in this report, there was reduction in the haematological parameters observed during malnutrition. However, after treatment, all the parameters were increased (though not all the increase were significant) in all animal groups. This is also in accordance with the report of researchers which have shown that several protein-rich foods increase Hb concentrations in human and animal studies. The significant increase seen in MCV and MCH when PEM group was compared with PC group may be due to increase abnormal size of the red blood cell that indicates low vitamin 12 or folate level that accompanies malnutrition. In contrast, the significant decrease level observed in MCV and MCH when PEM group was compared with MO and FM groups suggested that the $M$. oleifera and fish meal are effective in combating anaemia. It is well known that protein malnutrition affects several morphological parameters in the blood. This was shown not only in mammals but also in birds and fish. In the research conducted on rats, feeding protein-deficient diet (9.5\% of protein) for 80 days significantly reduced hemoglobin, MCV and MCH concentration and increased MCHC level [20]. Protein deprivation (from $24 \%$ to $13 \%$ of crude protein) caused the decrease of RBC number and MCV level and increased the MCH and MCHC in fingerlings of Cyprinus Carpio [21]. Similarly, Mohamed et al., (2012) [22] observed a reduction of MCV and $\mathrm{MCH}$ level in birds fed lower protein content diet (21\% in comparison to $23 \%$ of crude protein).

\section{Conclusion}

The present study reveals that defatted $M$. oleifera seed extract has some obvious therapeutic implications against anaemia induced by Protein Energy Malnutrition. Defatted M. oleifera seed extract with its multiple beneficiary properties would seem useful as an adjuvant for the prevention and/or management of anaemia.

\section{Compliance with ethical standards}

\section{Acknowledgments}

The contributions of laboratory staff of the Department of Biochemistry, Kogi State University are hereby acknowledged.

\section{Disclosure of conflict of interest}

The authors declare no conflict of financial or ideological interest.

\section{References}

[1] Word Health Organization. Malnutrition . 2017.

[2] Bharadwaj, S, Ginoya, S, Tandon, P, Gohel T.Guirguis J, Vallabh, H., Hanouneh, I. Malnutrition: Laboratory markers vs nutritional assessment. Gastroenterology Report. 2016; 4(4): 272-280.

[3] Primavera Borelli, Solange L. Blatt, Marcelo M. Rogero, Ricardo A. Fock. Haematological alterations in protein malnutrition, Rev. Bras. Hematol. Hemoter. 2004; 26(1). 
[4] Waterlow JC. Malnutrición proteico-energetica. Organización Panamericana de la Salud (Publicação científica n 555). Washington. 1996; 501.

[5] Chandra RK, Kumari S. Nutrition and immunity: an overview. J Nutr. 1994; 124(8 suppl): 1433S-1435S.

[6] Olayinka LM, Bewaji CO. Protective role of Moringa oleifera leaf-based diet on protein- energy malnutrition induced skeletal muscle degeneration. Int J Sci Rep. 2017; 3(2): 54-62.

[7] Jegede ER, Bewaji CO, Didunyemi OM. "Interactions of Moringa oleifera Seed (Lam) With Cations Transport Adenosine Triphosphatases in Protein Energy Malnourished Rats Skeletal Muscle." IOSR Journal of Pharmacy and Biological Sciences (IOSR-JPBS). 2018; 13(3): 78-85.

[8] Mughal M, H Ali G, Srivastava PS, Iqbal M. Improvement of drumstick (Moringa Pterygosperma Gaertn)- a unique source of food and medicine through tissue culture. Hamdard Med. 1999; 42: 37-42.

[9] Anwar F, Bhanger M, I Analytical characterization of Moringa oleifera seed oils grown in temperate regions of Pakistan. J. Agric. Food Chem. 2003; 51: 6558-6563.

[10] Anwar F, Latif S, Ashraf M, Gilani AH. Moringa oleifera: a food plant with multiple medicinal uses. Phytother Res. 2007; 21: 17-25.

[11] Amaglo NK, Bennett RN, Lo Curto RB, Rosa EAS, Lo Turco V, Giuffrid A, Profiling selected phytochemicals and nutrients in different tissues of the multipurpose tree Moringa oleifera L., grown in Ghana. Food Chem. 2010; 122: 1047-51.

[12] Bamishaiye EI, Olayemi FF, Awagu EF, Bamshaiye OM. Proximate and Phytochemical Composition of Moringa oleifer Leaves at Three Stages of Maturation. Advance J Food Sci Technol. 2011; 3(4): 233-7.

[13] Siddhuraju P, Becker K. Antioxidant Properties of Various Solvent Extracts of Total Phenolic Constituents from Three Different Agroclimatic Origins of Drumstick Tree (Moringa oleifera Lam.) leaves. J Agricultural Food Chem. 2003; 51(8): 2144-55.

[14] Oyagbemi AA, Odetola AA, Azeez OI. Ameliorative effects of Cnidoscolus aconitifolius on anaemia and osmotic fragility induced by protein energy malnutrition. African Journal of Biotechnology. 2008; 7(11): 1721-1726.

[15] Bray G, Smith S, de Jonge L, Xie H, Rood J, Martin CK, Redman LM. Effect of dietary protein content on weight gain, energy expenditure, and body composition during overeating: A randomized controlled trial. The ournal of the American Medical Association. 2012; 307(1): 47-55.

[16] Lewicki S, Lewicka A, Kalicki B, Kłos A, Bertrandt J, Zdanowski R. The influence of vitamin B12 supplementation on the level of white blood cells and lymphocytes phenotype in rats fed a low-protein diet. Central European Journal of Immunology. 2014; 4: 419-425.

[17] Borelli P, Blatt S, Pereirra J, deMaurino BB, Tsujita M, deSonja AC. Reduction of Erythroid Precursors in ProteinEnergy Malnutrition. Br J Nutr. 2007; 97: 2.

[18] Bolarinwa AF, Ajayi FF, Alak 00, Akande 00. Effect of Malnutrition on Basal and Induced Gastric Acid Secretion. Nig J Physiol Sci. 1991; 5: 144-8.

[19] Sławomir L, Monika L, Jerzy B, Bolesław K, Jacek Z. Kubiak, Aneta Lewicka . The long-term effect of a proteindeficient-diet enriched with vitamin B6 on the blood parameters in unexercised and exercised rats. Journal of Food and Agricultural Immunology. 2018; 29(1): 722-734.

[20] Prestes-Carneiro LE, Laraya RD, Silva PR, Moliterno RA, Felipe I, Mathias PC. Long-term effect of early protein malnutrition on growth curve, hematological parameters and macrophage function of rats. Journal of Nutritional Science and Vitaminology. 2006; 52(6): 414-420.

[21] Al-Sraji AY, Nasir NA. Effect of different dietary protein and fats on some biochemical blood parameters in common carp fingerlings (Cyprinus Carpio L) reared in float cages. Asian Journal of Experimental Biological Sciences. 2013; 4(2): 293-296.

[22] Mohamed EAA, Ali OHA, Malik HEE, Yousif IA. Effect of season and dietary protein level on some haematological parameters and blood biochemical compositions of three broiler strains. International Journal of Poultry Science. 2012; 11(12): 787-793. 